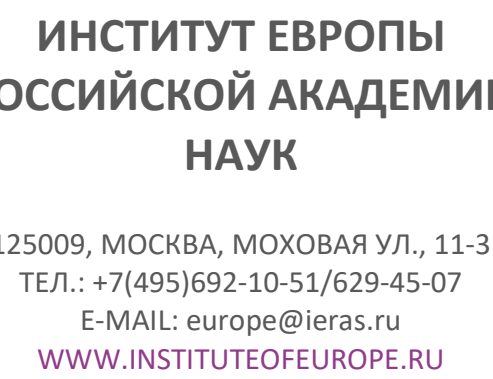

ИНСТИТУТ ЕВРОПЫ HАУК

INSTITUTE OF EUROPE RUSSIAN ACADEMY OF SCIENCES

125009, MOSCOW, MOKHOVAYA STR., 11-3

TEL.: +7(495)692-10-51/629-45-07

E-MAIL: europe-ins@mail.ru WWW.INSTITUTEOFEUROPE.RU

Статья в журнале «Аналитические записки Института Европы РАН»

№1, 2021 (№231)

\title{
Выборы нового председателя Христианско-демократического союза Германии
}

\section{Владислав Борисович Белов}

кандидат экономических наук, ведущий научный сотрудник, заместитель директора по научной работе, заведующий Отделом страновых исследований, руководитель Центра германских исследований Института Европы РАН

Аннотация. 16 января 2021 г. на съезде ХДС, промедшем в онлайн-формате, был избран новый председатель партии. Им стал премьер-министр земли Северный Рейн - Вестфалия Армин Лашет, сменивший на этом посту Аннегрет Крамп-Карренбауэр. Вопреки большинству прогнозов он выиграл у фаворита Фридриха Мериа. Автор анализирует значение этого события для ХДС, оченивает перспективы партии в рамках года супервыборов в Германии, прогнозирует развитие российско-германских отнотений.

Ключевые слова: Германия, ХДС, партийный съезд, А. Меркель, А. Крамп-Карренбауэр, А. Лашет, Ф. Мери, Н. Рёттген, российско-германские отношения.

\footnotetext{
Автор. Белов Владислав Борисович - кандидат экономических наук, ведущий научный сотрудник, заместитель директора по научной работе, руководитель Отдела страновых исследований, руководитель Центра германских исследований ИЕ РАН. Адрес: 125009, Россия, Москва, ул. Моховая, д. 11, стр. 3. Email: vladisbelov@yandex.ru.
}

DOI: http://doi.org/10.15211/analytics12021 
В начале февраля 2020 года председатель ХДС, избранная на этот пост в декабре 2018 г., Аннегрет Крамп-Карренбауэр (АКК) после скандальных событий в ландтаге Тюрингии заявила о готовности уйти в отставку.

Внеочередной съезд ${ }^{1}$ был назначен на конец апреля, затем в связи с пандемией дважды перенесён - сначала на начало декабря, затем на середину января 2021 года.

К концу февраля определилась тройка кандидатов на пост руководителя партии. Первым стал Армин Лашет - премьер-министр крупнейшей федеральной земли Северный Рейн - Вестфалия, сформировавший дуумвират с Йенсом Шпаном, главой федерального министерства здравоохранения. Вторым был Фридрих Мерц, с минимальным преимуществом уступивший АКК на съезде в декабре 2018 г. и решивший возвратиться в активную политику. Третьим стал Норберт Рёттген - руководитель внешнеполитического комитета Бундестага, в 2012 г. отправленный А. Меркель в отставку с поста министра окружающей среды.

В 2020 году бесспорным фаворитом считался Ф. Мерц, лидировавший в опросах вплоть до начала 2021 г. На фоне вяло текущей предвыборной борьбы за пост председателя он существенно опережал своих соперников. При этом содержательные дискуссии между кандидатами начались только в конце года. Их отличительной чертой был достаточно дружелюбный характер, основанный на взаимном уважении. Главными темами дискуссии стали вопросы климата, энергетического и цифрового перехода, миграции, социального и гендерного равенства, борьбы с пандемией и преодоления её последствий.

К основным преимуществам Мерца эксперты относили его управленческие и предпринимательские навыки, готовность жёсткой рукой «наводить порядок» в партии и возвращать её к ордолиберальным ценностям. У А. Лашета таким преимуществом считался опыт руководства крупнейшей землёй Германии, где он с успехом в сентябре 2020 г. провёл коммунальные выборы, а также обеспечил эффективную борьбу с пандемией, учитывающую интересы местного населения. В пользу Н. Рёттгена говорила его работа в федеральном правительстве, а также внешнеполитические компетенции.

В конце октября правление ХДС приняло решение перенести съезд на середину января. Это вызвало протест находившегося на пике популярности Ф. Мерца, заявившего о заговоре партийной верхушки против него. Поняв, что это был ошибочный шаг, он отказался от своих слов, но, тем не менее, потерял часть симпатизирующих ему партийцев. Одновременно в СМИ попала информация об участии А. Лашета в сделке с поставками защитных масок и лоббировании интересов одной из немецких компаний, что отрицательно повлияло на его рейтинг.

Все три политика были готовы стать кандидатами на пост федерального канцлера от блока ХДС/ХСС, понимая, что им будет противостоять премьер-министр Баварии и председатель Христианско-социального союза Маркус Зёдер, до последнего времени отрицавший свою готовность принять такое предложение. Примечательным стал вброс в немецкие СМИ за пару недель до съезда информации о готовности Й. Шпана

\footnotetext{
${ }^{1}$ Белов В.Б. Тюрингия: новое политическое землетрясение в Германии. Аналитическая записка №1, 2020 (№184). URL: https://www.instituteofeurope.ru/images/uploads/analitika/2020/an184.pdf
} 
выдвинуть свою кандидатуру (в случае избрания А. Лашета), которую тот с некоторым опозданием опроверг.

К середине января рейтинги кандидатов заметно сблизились, но фаворитом оставался Мерц. Съезд, работа которого была организована в онлайн-формате ${ }^{2}, 15$ января открыли АКК и А. Меркель. Примечательно, что бундесканцлерин в своей речи не дала оценки деятельности АКК как председателя партии. Аннегрет Крамп-Карренбауэр ${ }^{3}$, критически оценив итоги своего председательства, подчеркнула личный вклад в восстановление отношений между ХДС и ХСС, оказавшихся в кризисе в 2018 году.

16 января с программными заявлениями выступили Лашет, Мерц и Рёттген (в алфавитном порядке). Речь премьер-министра СРВ оказалась наиболее содержательной и эмоциональной. Возможно, это стало одним из факторов, определивших итоги голосования: он набрал почти такое же количество голосов, как и его основной оппонент (380 против 385). Рёттген получил 224 голоса. По итогам второго тура за Лашета проголосовал 521 депутат, за Мерца - 466. Очевидно, победу обеспечили представители женского и молодёжного крыла ХДС, симпатизировавшие Рёттгену и выступавшие против Мерца. Окончательный результат во многом стал неожиданным для экспертного сообщества - лишь немногие прогнозировали победу Лашета.

Оппоненты поздравили победителя и сказали, что конкуренция внутри партии закончилась и теперь будет идти только с другими политическими силами. Они пообещали ему поддержку и совместную работу.

Съезд, который с технической точки зрения прошёл безупречно ${ }^{4}$, также избрал правление и президиум ХДС, в который вошёл Рёттген. Итоги цифрового голосования депутаты должны подтвердить письмами ${ }^{5}$. Окончательно они будут подведены 22 января. Каких-либо сюрпризов и существенных отклонений ожидать не следует (депутатам было запрещено фотографировать или иным способом фиксировать своё волеизъявление).

Мерц, несмотря на неоднократные просьбы, отказался от избрания в президиум, объяснив это решением не сокращать квоту для женских коллег. Одновременно он предложил Лашету свою кандидатуру на пост федерального министра экономики и энергетики, который занимает Петер Альтмайер, чем немало удивил всех («обратился не

\footnotetext{
${ }^{2}$ В отличие от съездов других партий, проходивших в смешанном формате, ХДС провёл своё мероприятие полностью дистанционно - все делегаты участвовали в удалённом режиме. Кандидаты и ведущие были в отдельной студии.

${ }^{3}$ АКК пробыла на посту председателя ХДС 771 день (2018-2021), т.е. больше, чем Л. Эрхард - 426 дней (1966-1967), В. Шойбле - 520 (1998-2000), Р. Барцель - 617 (1971-1973). Абсолютным рекордсменом является Г. Коль - 9 тыс. 279 дней (1973-1998). На втором месте А. Меркель - 6 тыс. 815 дней (2000-2018). ${ }^{4}$ Единственным исключением стало отсутствие голосовой связи с делегатом Хансом-Вернером Адамсом. Несмотря на включённый микрофон, он не смог передать своё послание («успех состоит в соединении экономической, социальной и климатической политики») кандидатам на пост председателя, находившимся в студии.

${ }^{5}$ Генеральный секретарь ХДС П. Цимяк сообщил о хакерских атаках на сервер съезда, которые были успешно отражены, и о том, что с этой точки зрения объективность цифровых итогов голосования не подлежит сомнению.
} 
по адресу»). Глава правительства А. Меркель ответила повторным отказом (в 2018 г. он уже обращался к ней с этой просьбой), сказав, что не собирается изменять нынешний состав правительства. Лашет пообещал обсудить с Мерцем вопрос его участия в партийной работе. Однако, похоже, последний не заинтересован в этом.

Шпан был избран одним из пяти заместителей Лашета, получив наименьшее количество голосов. Одна из причин - негативное впечатление, которое он произвёл на делегатов, выступив в рамках раунда вопросов к кандидатам с «пламенной речью» в поддержку своего партнёра по дуумвирату ${ }^{6}$. Такую рекламу большинство посчитало нарушением этических норм.

Что ожидает партию в ближайшее время?

Главой партии стал опытный, зрелый и уверенный в своих способностях политик. Его взгляды близки к позиции А. Меркель. Его цель - возврат ХДС к обновлённым консервативным ценностям и усиление её позиций как ведущей силы политического центра/середины. 2021 - это «год супервыборов», в рамках которого пройдёт пара коммунальных, шесть земельных и одни федеральные выборы ${ }^{7}$, где христианские демократы должны не только победить, но и добиться возврата электората, перешедшего в последние годы к протестным партиям (в основном, к «Альтернативе для Германии» (АдГ) и «Союзу 90/Зелёные»).

А. Лашет и А. Меркель, будучи единомышленниками, способны организовать эффективную предвыборную кампанию. Новый председатель готов стать кандидатом на пост канцлера и вовлечь своих коллег в командную работу. Он будет стремиться организовать консенсус на всех партийных уровнях и добиваться сближения либерального, консервативного и социального крыльев. В этом отношении у него не только больше опыта и компетенций по сравнению с Ф. Мерцем, но и больше управленческой харизмы. Он в какой-то степени похож на М. Зёдера, с которым у него сложились хорошие отношения в рамках взаимодействия федеральных земель. Баварский лидер, поздравив коллегу с победой, подчеркнул, что они будут вместе и «дальше писать историю успеха» союза ХДС/ХСС, а также искать «совместные, умные и конструктивные решения». Одновременно ему удалось избежать упоминания вопроса о канцлерстве ${ }^{8}$. Но в скором времени Зёдеру придётся вернуться к нему. По всей видимости, это состоится после мартовских коммунальных выборов в Гессене и земельных в Рейнланд-Пфальце и Баден-Вюртемберге. Несмотря на то что у ХДС неплохие шансы на хорошие результаты, партии есть смысл подстраховаться и

\footnotetext{
6 По всей видимости, он решил наверстать упущенное. До этого Лашет как один из кандидатов практически не получал от него поддержки. Шпан вёл себя как «независимый» политик, популярность которого в условиях борьбы с пандемией к концу году существенно выросла.

714 марта будут избирать коммунальных и муниципальных депутатов в Гессене и одновременно земельных депутатов в Баден-Вюртемберге и Рейнланд-Пфальце. Выборы в ландтаги также пройдут 6 июня в Саксонии-Ангальте, 26 сентября - в Мекленбург - Передней Померании, Тюрингии и Берлине. В тот же день состоится избрание нового состава Бундестага. 12 сентября пройдут коммунальные выборы в Нижней Саксонии. См.: Wahltermine. https://www.wahlrecht.de/termine.htm (дата обращения: 16.01.2021)

${ }^{8}$ Merz will Wirtschaftsminister werden - Merkel erteilt Absage. 16.01.2021. https://www.tagesspiegel. de/politik/digitaler-cdu-parteitag-merz-will-wirtschaftsminister-werden-merkel-erteilt-absage/26793558.html (дата обращения: 16.01.2021)
} 
определиться со своим кандидатом несколько позже - на тот случай, если христианские демократы получат невысокие результаты, и кандидат не будет нести ответственности за них. Эксперты не исключают, что наряду с Зёдером участие в борьбе за этот пост может принять Й. Шпан.

Лашет заявил о готовности сотрудничать со всеми демократическими партиями, подчеркнув, что в то же время предстоит жёсткая борьба с ними за места в ландтагах и Бундестаге. Наиболее сложным, на его взгляд, будет противостояние с АдГ, планирующей агрессивную кампанию (и к демократическим не относящейся).

Председатель СвДП Линднер выразил надежду на формирование на федеральном уровне коалиции с ХДС/ХСС, высказав удовлетворение работой чёрно-жёлтой коалиции в СРВ во главе с нынешним премьером земли: «то, что было невозможно с Меркель ${ }^{9}$, становится возможным с Армином Лашетом». Но для этого свободным демократам надо набрать не менее 10\% голосов на сентябрьских выборах в Бундестаг, что на сегодняшний день представляется маловероятным.

Кандидат в канцлеры от СДПГ, федеральный министр финансов О. Шольц, рассматривая Лашета как лидера партии, с которым социал-демократам предстоит вести предвыборную борьбу, пообещал ему конструктивное взаимодействие в рамках существующей коалиции, в первую очередь, в рамках борьбы с пандемией. Руководство партий блока и социал-демократов отрицает возможность повторения «Большой коалиции» в третий раз подряд.

Отметим, что среди трёх кандидатов А. Лашет занимал и занимает наиболее конструктивную позицию по отношению к России. Следуя политическому мэйнстриму и критикуя Кремль в отношении Крыма и Украины, он выступает за последовательное развитие сотрудничества с РФ. В этом смысле показательно его выступление в Бонне в июле 2019 г. на открытии общественного форума «Петербургский диалог», которое можно считать программным для германо-российских отношений.

\section{Выводы}

Избрание А. Лашета председателем ХДС и, соответственно, проигрыш Ф. Мерца, стали неожиданными для экспертного сообщества. Итоги выборов выявили раскол в партии, который новому руководству предстоит преодолеть и одновременно найти путь к достижению консенсуса между разными течениями в партии. Сторонники Мерца и Рёттгена критикуют Лашета за близость его взглядов с позицией А. Меркель. Они считают, что он продолжит политику «Так и дальше» (,Weiter so“), которая, с их точки зрения, будет означать отсутствие партийных реформ. Представляется, что это стереотип, который новая команда А. Лашета сможет опровергнуть и постепенно завоевать лояльность оппонентов. Времени для изменений очень мало. Первые результаты можно будет оценить после земельных выборов весной текущего года.

\footnotetext{
${ }^{9}$ В ноябре 2017 г. Линднер единолично принял решение о выходе из переговоров о т.н. ямайской коалиции в составе ХДС/ХСС, «Зелёные/Союз 90» и СвДП.
} 
В ближайшие недели Лашету предстоит показать себя новым лидером партии, который, с одной стороны, солидарен с бундесканцлерин в понимании дальнейшего развития ХДС, а, с другой, самостоятелен и независим в определении конкретных действий и как председатель, и как премьер крупнейшей федеральной земли. Тогда он может рассчитывать на рост своего рейтинга, необходимый для борьбы за пост кандидата в канцлеры и укрепления авторитета.

Что касается будущего правительства, то на сегодняшний день, по нашим оценкам, наиболее вероятен следующий вариант развития событий: М. Зёдер избирается кандидатом на пост канцлера, по итогам выборов в Бундестаг формируется коалиция ХДС/ХСС с зелёными во главе с баварским лидером и вице-канцлером А. Бэрбок (или Р. Хабеком), А. Лашет становится президентом Бундестага.

Другие сценарии также возможны. Не исключено, что М. Зёдер поддержит кандидатуру А. Лашета и откажется от предстоящего канцлерства. В отличие от Мерца, он рассматривает нового председателя в большей степени как партнёра, а не как конкурента.

Несмотря на критическую позицию зелёных по отношению к России, российскогерманское сотрудничество сохранит своё поступательное движение в сфере экономики, культуры, науки и образования. В политической сфере не исключен период очередного охлаждения, который относительно быстро будет преодолён.

Дата выпуска: 17 января 2021 года.

Series of articles in journal «Analytical papers of the Institute of Europe RAS»

№1, 2021 (№231)

\title{
The new CDU chairman election
}

\begin{abstract}
Author. Vladislav Belov, Candidate of Sciences (Economics), Deputy Director of IE RAS, Head of the Department for Countries Studies, Head of the Center for German Studies, Institute of Europe, Russian Academy of Sciences. Address: 11-3, Mokhovaya str., Moscow, Russia, 125009. E-mail: vladisbelov@yandex.ru.
\end{abstract}

Abstract. On January 16, 2021, online congress of the CDU elected a new party chairman - the Prime Minister of North Rhine-Westphalia, Armin Lachette, who replaced Annegret Kramp-Karrenbauer. In contrast to most predictions, Armin Lachette won against the favorite Friedrich Merz. The author analyzes the significance of the event for $C D U$, assesses the party's prospects for the year of superelections in Germany, and predicts the development of Russian-German relations.

Keywords: Germany, CDU, party congress, A. Merkel, Annegrett Kramp-Karrenbauer, A. Laschet, F. Merz, N. Roettgen, Russian-German relations.

DOI: http://doi.org/10.15211/analytics12021

http://www.zapiski-ieran.ru

Release date: January 17, 2021. 